\title{
Yield and yield components of maize as influenced by row arrangement, nitrogen and phosphorus levels in maize (Zea mays L)/ castor (Ricinus communis) mixture
}

\author{
Arunah U.L*; E. B. Amans; M. Mahmud; A. Ahmed; G.L. Luka; A. S. Isah; \\ B.A. Babaji; E.C. Odion \\ * Correspondent address: Department of Agronomy, Ahmadu Bello University, Zaria
}

\begin{abstract}
Field experiment was conducted at Institute for Agricultural Research farm Samaru, Zaria in Nigeria during 2007 to 2009 rainy seasons. Treatments consisted of factorial combinations of three alternate row arrangements of maize: castor in 1:1, 1:2 and 2:1, four levels of nitrogen $\left(0,40,80\right.$ and $\left.120 \mathrm{~kg} \mathrm{~N} \mathrm{ha}^{-1}\right)$ and three levels of phosphorus $\left(13,26\right.$ and $\left.39 \mathrm{~kg} \mathrm{P} \mathrm{ha}^{-1}\right)$, in a split plot design with three replication. Nitrogen and phosphorus fertilizer were assigned to the main plots and row arrangements to the sub-plots. Row arrangement of 1:2 significantly increased cob weight, while 2:1 increased 100- grain weight and yield of maize. Applied 40 $\mathrm{kg} \mathrm{N} \mathrm{hat} \mathrm{resulted} \mathrm{in} \mathrm{significantly} \mathrm{heavier} \mathrm{cob} \mathrm{diameter} \mathrm{and} \mathrm{grain} \mathrm{yield} \mathrm{in} \mathrm{2009.} \mathrm{Application} \mathrm{of} 80 \mathrm{~kg} \mathrm{~N} \mathrm{ha}$ increased cob diameter and weight in 2007. Cob weight in 2009, 100- grain weight and yield in 2007 responded up to $120 \mathrm{~kg} \mathrm{Nh}^{-1}$. Application of $39 \mathrm{~kg} P \mathrm{ha}^{-1}$ was observed to increased 100- grain weight, while grain yield did not responded beyond applied $26 \mathrm{~kg} P \mathrm{ha}^{-1}$. Maize can be intercropped with castor at 2:1 row arrangement with application of $120 \mathrm{~kg} \mathrm{~N} \mathrm{ha}{ }^{-l}$ plus $26 \mathrm{~kg} \mathrm{P} \mathrm{ha}{ }^{-l}$.
\end{abstract}

Key words; cob, nitrogen, phosphorus, row arrangement, yield

\section{Introduction}

Maize is grown in mixture with cereals, legumes, tubers and oil seed crops, thus increasing its expanse of cultivation and acceptability among farmers [1]. However, little information is known about its cultivation with castor. Castor provides natural resource for Biodiesel, soap and its oil residue is used in fertilizer [2]. The problem of producing these crops in mixture might be basically shading effect from the castor plant due to its broad leaf nature, which might reduce assimilate translocated to yields and yield components of maize. Thus cultivating these crops in mixture will help improve the financial status of our poor resource famers. Application of nitrogen and/ or phosphorus has been observed to increase yields generally in savanna soil, due to low inherent fertilities of our soils. And these two nutrients are important in growth and root developments, thus help in yield improvement [3] and [4]. Sole fertilizer requirement for maize is known but, little is known about the fertility requirement for castor. For the mixture of the two crops very little is known in Nigeria as it is not a common practice. This poses a serious challenge of the need in investigating the fertilizer requirement of these crops in mixture to improve maize yield potential. The study was thus carried out to investigate the most appropriate row arrangement, optimum nitrogen and phosphorus levels for maize productivity.

\section{Materials And Methods}

The experiment was conducted at the Institute for Agricultural Research farm Samaru, Zaria $\left(11^{\circ} 11^{\prime} \mathrm{N}\right.$ $07^{\circ} 38^{\prime} \mathrm{E}, 686 \mathrm{~m}$ above sea level) in the Northern Guinea Savanna zone of Nigeria during the 2007, 2008 and 2009 rainy seasons. Treatments consisted of factorial combinations of three alternate row arrangements of maize: castor in 1:1, 1:2 and 2:1, four levels of nitrogen $\left(0,40,80\right.$ and $\left.120 \mathrm{~kg} \mathrm{~N} \mathrm{ha}^{-1}\right)$ and three levels of phosphorus $\left(13,26\right.$ and $\left.39 \mathrm{~kg} \mathrm{P}^{-1}\right)$. The treatments were laid out in a split plot design and replicated three times. Nitrogen and phosphorus fertilizer treatments were factorially combined and assigned to the main plots while row arrangements were assigned to the sub-plots. Nitrogen fertilizer (Urea) was applied as per treatment, in two equal doses by side placement at 3 and 6 WAS after the first and second weeding respectively. The phosphorus fertilizer (in the form of SSP) in amount according to treatments was applied at sowing. The net plot size varied with row arrangement of 1:1, 2:1 and 1:2 (50:50, 33:67, and 67:33). Row spacing of $75 \mathrm{~cm}$ and plant spacing of 25 and $40 \mathrm{~cm}$ were adopted for maize and castor respectively.

Data were collected on cob length, cob diameter, cob weight, 100- grain weight and yield. These were analysed statistically in accordance with [5]. The means were compared using Duncan Multiple Range Test [6].

\section{Results And Discussion}

The analysis shows that the soil was loamy in nature from $0-30 \mathrm{~cm}$ depth for the three years, except at $15-30 \mathrm{~cm}$ in 2008 where it was clay loam in nature (Table 1). The organic carbon, total nitrogen and available 
phosphorus were generally low in the three years of the study. The low level of nutrient might be due to the poor parent material of the soil, heavy rainfall experienced in the savanna, high temperatures and inadequate use of fertilizers.

The effect of row arrangement, nitrogen and phosphorus application on maize cob length, cob diameter, cob weight, 100- grain weight and grain yield during 2007, 2008 and 2009 rainy seasons are shown in Table 2. Row arrangements significantly increased cob weight only in 2007 and 2009, 100- grain weight in 2007 and grain yield in the three years. The result showed that 1:2 arrangement resulted in heavier cobs than the other arrangement, while 2:1 recorded the least cob weight in both years. The 100- grain weight was significantly increased by row arrangement of $2: 1$ than to the other row arrangements that were statistically at par. Heavier grain yield was obtained with 2:1 than to the other two arrangements, the least yield was with 1:2 throughout the study years. The higher maize yield obtained with $2: 1$ row arrangement could be due to higher maize population at this arrangement. The longer and heavier cob with 1:2 might be attributed to better light interception used in the production of assimilates that was translated to these yield components. [7] and [8] reported similar findings. Nitrogen application significantly increased all the measured parameters in the years except on cob length and diameter in 2008. Application of nitrogen from 0 to $40 \mathrm{~kg} \mathrm{~N}$ ha $^{-1}$ produced longer and wider cobs in the affected years, beyond this level only cob diameter was significantly increased in 2007 with applied $80 \mathrm{~kg} \mathrm{~N} \mathrm{ha}^{-1}$. Increase in nitrogen from 0 to $40 \mathrm{~kg} \mathrm{~N}$ ha $^{-1}$ resulted in heavier cobs. Further increase to $80 \mathrm{~kg} \mathrm{~N}^{-1}$ was found to increase cobs weight only in 2007 and 2008. Beyond this level cob weight was not significantly increased except in 2008, where applied $120 \mathrm{~kg} \mathrm{~N}^{-1}$ recorded heavier cobs only than to applied 40 and $0 \mathrm{~kg} \mathrm{~N} \mathrm{ha}^{-1}$. Each level of applied nitrogen from 0 to $120 \mathrm{~kg} \mathrm{~N}$ ha $^{-1}$ resulted in heavier 100- grain weight only in 2007. Application of $120 \mathrm{~kg} \mathrm{~N}^{-1}$ was observed to increased 100- grain weight than other nitrogen levels in 2008 and 2009. However applied 40 and $80 \mathrm{~kg} \mathrm{~N}^{-1}$ had statistically similar 100- grain weight that was significantly heavier than the control. Application of $120 \mathrm{~kg} \mathrm{~N}^{-1}$ resulted in heavier grain yield in the years than when no nitrogen was applied. This level was however, observed to be at par with other applied nitrogen levels except in 2007 and 2008, where it recorded higher yield to applied $40 \mathrm{~kg} \mathrm{~N}^{-1}$ in 2008,40 and $80 \mathrm{~kg} \mathrm{~N}^{-1}$ in 2007. This could be attributed its importance in photosynthesis thus, increased rate of assimilate formation which was translated to longer, wider and heavier cobs, that might have resulted in heavier grains and yield. This could also be due to the low soil nitrogen (Table 1) of the experimental fields. Similar findings were reported by [9], [10] and [4].

Phosphorus application was significant only on cob length in 2008, cob diameter and grain yield in 2009, 100- grain weight in 2007 and 2008. Application of $13 \mathrm{~kg} \mathrm{P} \mathrm{ha}^{-1}$ produced longer cobs than $39 \mathrm{~kg} \mathrm{P}^{-1}$, but was significantly comparable to $26 \mathrm{~kg} \mathrm{P} \mathrm{ha}^{-1}$. Application of $39 \mathrm{~kg} \mathrm{P}^{-1}$ resulted in wider cobs and heavier 100- grain only than to applied $13 \mathrm{~kg} \mathrm{P}^{-1}$, except where it recorded higher 100- grain weight than to applied $26 \mathrm{~kg} \mathrm{P} \mathrm{ha}{ }^{-1}$. Grain yield responded up to applied $26 \mathrm{~kg} \mathrm{P}^{-1}$ beyond this level there was no significant increase in grain yield. The significant response of maize grain yield to application of phosphorus fertilizer, could be due to the role it plays in root establishment and development which might have assisted in increasing $\mathrm{N}$ absorption by the plant thus, increase assimilate produced. This might have been translated in the longer and wider cob, heavier 100- grain weight and maize yield. [11], [12] and [13] reported significant response of maize to application of $\mathrm{P}$ fertilizer.

The interaction between row arrangements and nitrogen levels on cob weight in 2007 and grain yield in 2007 and 2008, between nitrogen and phosphorus on cob weight in 2008 and grain yield in 2007 and 2008, as well as among row arrangement, nitrogen and phosphorus on grain yield in 2007 are presented in Table 3- 5. Row arrangement of 1:2 with applied $120 \mathrm{~kg} \mathrm{~N}^{-1}$ resulted in heavier cobs and the least weight was observed with the row arrangements without applied nitrogen. Row arrangement of 2:1 with applied $120 \mathrm{~kg} \mathrm{~N}^{\mathrm{ha}}{ }^{-1}$ resulted in higher grain yield and 1:1 without applied nitrogen in 2007 gave the least yield. In 2008, 2:1 arrangement with applied $80 \mathrm{~kg} \mathrm{~N}^{-1}$ hasulted in higher yield, this combination was also comparable to $2: 1$ and applied 40 and $80 \mathrm{~kg} \mathrm{~N}^{-1}$, and with 1:1 arrangement with application of $120 \mathrm{~kg} \mathrm{~N}^{-1}$. The least yield was observed with the various arrangements without applied nitrogen. This could due to the germination delay observed with the castor plant. This gave wider space for the maize plants at these row arrangements in making use of the environmental resources and available nutrient. The higher grain yield obtained at 2:1 row arrangement with the applied nitrogen level might be due to the higher maize population at this row arrangement was supplied with the nutrients needed. [14] Observed significant response of maize in mixtures to $\mathrm{N}$ fertilizer.

Combined application of $120+13 \mathrm{~kg} \mathrm{~N}+\mathrm{P} \mathrm{ha}^{-1}$ recorded higher cobs weight and the least weight was observed without applied nitrogen at all P levels. In 2007, application of 80 and $26 \mathrm{~kg} \mathrm{~N}+\mathrm{P}^{\text {ha }}{ }^{-1}$ recorded higher grain yield which was statistically at par with applied $120 \mathrm{~kg} \mathrm{~N}^{-1}$ plus 26 and $39 \mathrm{~kg} \mathrm{P}^{-1}$. The least yield was observed when no nitrogen was applied with applied 26 and $39 \mathrm{~kg} \mathrm{P}^{-1}$. Application of 120 with 13 $\mathrm{kg} \mathrm{N}+\mathrm{P}_{\text {ha }}^{-1}$ recorded higher grain yield which was statistically at par with applied $80 \mathrm{~kg} \mathrm{~N}^{-1}$ plus $26 \mathrm{~kg} \mathrm{P}$ $\mathrm{ha}^{-1}$ in 2008. The least yield was observed without applied nitrogen at $\mathrm{P}$ levels. Nitrogen and phosphorus are important for growth and development, might have led to higher photosynthetic activities that resulted in the 
production of enough assimilates for subsequent translocation for higher yield. The phosphorus could have help in root development that assisted the rate of nitrogen absorption. The synergic and compensation between the two elements might be the reason why both elements showed no response up to their highest combined levels. Similar significant findings were reported by, [15] and [16]. Row arrangement of 2:1 with combined application of $120 \mathrm{~kg} \mathrm{~N} \mathrm{ha}^{-1}+26 \mathrm{~kg} \mathrm{P}^{-1}$ resulted in the highest grain yield and the least yield was observed with 1:2 row arrangement and $0+13 \mathrm{~kg} \mathrm{~N}+\mathrm{P}^{-1}$.

\section{Conclusion}

Based on the finding of the studies, row arrangement of $1: 2$ with application of $120+26 \mathrm{~kg} \mathrm{~N}+\mathrm{P}^{-1}$ should be applied for the production of maize in maize/ castor mixture.

\section{References}

[1] Gobin, A.M.L, M.I Uguru and J. Deckens.(2001). Oil crops.Cited from Crop Products in Tropical Africa Romain, H., 2001 PP 726-732.

[2] Oplinger (1990). Castor Production. www.hort.purdue.edu/newcrop/afcm/index.html

[3] Mani, H; Tanimu, B; Mukhtar, A. A, Jaliya, M.M and Mahadi, M.A. (2005). Response of early and extra early maize (Zea.mays L.) Varieties to sowing dates in the Northern Guinea Savanna of Nigeria. Journal of Tropical Bioscience 5(1): 141-146.

[4] Aboyeji, C.M. (2008). Performance of extra early maize (Zea mays L.) as affected by rates of NPK fertilizer and Plant population in the Northern Guinea Savanna Zone of Nigeria. Unpublished MSc. Thesis, submitted to Postgraduate School, ABU, Zaria, 63194pp.

[5] Snedecor, G.W and W.G Cochran (1967) statistical methods $10^{\text {th }}$ ed. Iowa state university press. Ames, Iowa U.S.A 456 pp

[6] Duncan, D. B ( 1955). Multiple Range and Multiple "F" test Biometrics 11: 1-42.

[7] Adeyemi, A.A.; T.A.T. Wahua and A.O. Ayeni (2001). Effect of Cropping Patterns and NPK (15-15:15) Fertilizer Application on N, P, and K Uptake of Component Crops In: Cassava/Maize/Melon Intercrop. Industrial Crops and Products Volume 31, (1), Pages $185-19$

[8] Anonymous (2002). A hand book for innovative maize-legume intercropping. SACRED Africa, Bungoma, Kenya, May 2002. In Agrobrief number 4 Intercropping of Annual food crops. Martine Van Wolfswinkel, $20 \mathrm{pp}$

[9] Lawal, A.B. (2000). Response of cucumber (Cucumis sativa L.) to intercropping with maize (zea mays L.) and varying rate of FYM and inorganic fertilizer. Unpublished $\mathrm{PhD}$ dissertation, submitted to post graduate school, $\mathrm{ABU}$, Zaria, $267 \mathrm{pp}$.

[10] Nammaka A. (2003). Effect of sowing date and nitrogen levels on yield and yield components of Extra- Extra maize (Zea mays L.) inSuddan Savanna of Nigeria. Unpublished MSc thesis, submitted to post graduate school, ABU, Zaria, 163- 165pp.

[11] Hussaini M.A. (2000). Studied on irrigation scheduling, nitrogen and phosphorus fertilization of dry season maize (Zea mays L.) at Kadawa. Unpublished PhD Dissertation, submitted to Postgraduate School, ABU, Zaria, $283 \mathrm{p}$

[12] Sharma, R.K. (2003). Response of maize to phosphorus fertilization. Madras Agricultural Journal 60 (6) $541: 549$

[13] Gupta D.K; R.C. Guatan (2005). Response of maize to NPK and schedule of tassel removal. India Journal of Ecology 21(1) 73 - 74.

[14] Khan, Z; S. Ahmed and M.S. Nazar (1983). The impact of inorganic nitrogen on maize and soybean monoculture and mixed stand on yields. Pakistan Journal of agric Resources Vol. 8, No. 4 (3), 453- 457.

[15] Baba I.S.C. (2002). Effect of plant density and rate of NPK fertilizer on the performance of popcorn (Zea mays L.). Unpublished B.Agric Poject, submitted to Department of Agronomy, Ahmadu Bello University, Zaria.48pp

[16] Inyang, S.J. (2006). Effect of NPK fertilizer and plant density on the performance of quality protein maize (Zea maize L.) at Samaru, Nigeria. Unpublished M.Sc. Thesis, submitted to Postgraduate School, Ahmadu Bello University, Zaria.20-64pp

Table1: The physico-chemical properties of soil in the experiment site at Samaru in 2007, 2008 and 2009 rainy seasons

\begin{tabular}{lllllll}
\hline Physical composition (\%) & \multicolumn{2}{c}{$\mathbf{2 0 0 7}$} & \multicolumn{2}{c}{$\mathbf{2 0 0 8}$} & & $\mathbf{2 0 0 9}$ \\
& $\mathbf{0 - 1 5}$ & $\mathbf{1 5 - 3 0}$ & $\mathbf{0 - 1 5}$ & $\mathbf{1 5 - 3 0}$ & $\mathbf{0 - 1 5}$ & $\mathbf{1 5 - 3 0}$ \\
\hline Sand & 480 & 440 & 380 & 280 & 480 & 480 \\
Silt & 420 & 480 & 400 & 300 & 400 & 360 \\
Clay & 100 & 80 & 220 & 420 & 120 & 160 \\
Textural class & Loam & Loam & Loam & Clay loam & Loam & Loam \\
Chemical composition & & & & & \\
pH in water & 6.29 & 5.00 & 6.20 & 4.90 & 5.90 & 5.60 \\
pH in 0.01 ml CaCl & 4.85 & 4.00 & 4.50 & 3.90 & 5.20 & 5.10 \\
Organic carbon (\%) & 0.76 & 0.66 & 0.84 & 0.56 & 0.52 & 0.48 \\
Total Nitrogen (\%) & 0.13 & 0.13 & 0.18 & 0.15 & 0.14 & 0.10 \\
Available phosphorus (ppm) & 12.60 & 14.07 & 13.80 & 15.10 & 12.25 & 5.25 \\
Exchangeable bases (Cmol kg $\left.{ }^{-1}\right)$ & & & & & \\
Ca & 3.74 & 2.21 & 4.17 & 8.33 & 1.00 & 0.80 \\
Mg & 0.77 & 0.55 & 1.42 & 2.64 & 0.60 & 0.69 \\
K & 0.20 & 0.30 & 0.33 & 0.35 & 0.23 & 0.15 \\
Na & 0.19 & 0.25 & 0.30 & 0.35 & 1.20 & 1.60 \\
CEC & 5.69 & 12.21 & 7.60 & 14.80 & 5.30 & 5.80 \\
\hline
\end{tabular}


Yield and yield components of maize as influenced by row arrangement, nitrogen and phosphorus

Table 2: Effect of row arrangement, levels of nitrogen and phosphorus on maize cob length, diameter and weight, 100-grain weight and yield during rainy seasons of 2007, 2008 and 2009

\begin{tabular}{|c|c|c|c|c|c|c|c|c|c|c|c|c|c|c|c|}
\hline \multirow[b]{2}{*}{ Treatments } & \multicolumn{3}{|c|}{ Cob length (cm) } & \multicolumn{2}{|c|}{ Cob diameter $(\mathrm{mm})$} & \multicolumn{3}{|c|}{ Cob weight (g) } & \multicolumn{2}{|c|}{ 100- grain weight (g) } & \multicolumn{3}{|c|}{ Grain yield $\left(\mathrm{kg} \mathrm{ha}^{-1}\right)$} & \multirow[b]{2}{*}{2008} & \multirow[b]{2}{*}{2009} \\
\hline & 2007 & 2008 & 2009 & 2007 & 2008 & 2009 & 2007 & 2008 & 2009 & 2007 & 2008 & 2009 & 2007 & & \\
\hline \multicolumn{16}{|c|}{ Row arrangement } \\
\hline $1: 1$ & 8.3 & 8.2 & 16.9 & 3.72 & 5.23 & 3.44 & $130.1 \mathrm{~b}$ & 100.9 & $132.7 \mathrm{~b}$ & $21.3 b$ & 23.7 & 27.3 & $814 \mathrm{~b}$ & $879 b$ & $1098 \mathrm{~b}$ \\
\hline $1: 2$ & 8.5 & 8.3 & 17.9 & 3.90 & 5.39 & 3.51 & $139.0 \mathrm{a}$ & 96.5 & $135.1 \mathrm{a}$ & $20.2 b$ & 22.9 & 28.9 & $532 \mathrm{c}$ & $580 \mathrm{c}$ & $743 c$ \\
\hline $2: 1$ & 8.4 & 8.1 & 17.4 & 3.74 & 5.39 & 3.46 & $115.9 \mathrm{c}$ & 86.6 & $120.0 \mathrm{c}$ & $23.5 \mathrm{a}$ & 24.4 & 28.8 & $1061 \mathrm{a}$ & $1059 \mathrm{a}$ & $1546 \mathrm{a}$ \\
\hline $\mathrm{SE} \pm$ & 0.09 & 0.08 & 0.42 & 0.09 & 0.15 & 0.07 & 2.52 & 5.18 & 3.02 & 0.51 & 0.68 & 1.47 & 19.5 & 48.0 & 66.8 \\
\hline \multicolumn{16}{|c|}{$\mathrm{N}$ levels $\left(\mathrm{kg} \mathrm{ha}^{-1}\right)$} \\
\hline 0 & $7.7 \mathrm{~b}$ & 8.0 & $13.1 \mathrm{~b}$ & $3.11 \mathrm{c}$ & 5.16 & $3.11 \mathrm{~b}$ & $89.3 \mathrm{c}$ & $47.9 \mathrm{c}$ & $84.8 \mathrm{~d}$ & $15.9 \mathrm{~d}$ & $13.5 \mathrm{c}$ & $19.4 \mathrm{c}$ & $571 d$ & $369 \mathrm{c}$ & $467 \mathrm{~b}$ \\
\hline 40 & $8.6 \mathrm{a}$ & 8.3 & $17.8 \mathrm{a}$ & $3.78 b$ & 5.22 & $3.54 \mathrm{a}$ & $127.1 \mathrm{~b}$ & $96.6 \mathrm{~b}$ & $128.9 \mathrm{c}$ & $19.3 \mathrm{c}$ & $25.2 \mathrm{~b}$ & $27.0 \mathrm{~b}$ & $800 \mathrm{c}$ & $891 b$ & $1206 \mathrm{a}$ \\
\hline 80 & $8.6 \mathrm{a}$ & 8.2 & $18.6 \mathrm{a}$ & $4.17 \mathrm{a}$ & 5.44 & $3.57 \mathrm{a}$ & $148.4 \mathrm{a}$ & $109.8 \mathrm{ab}$ & $146.4 \mathrm{~b}$ & $22.8 b$ & $26.8 \mathrm{~b}$ & $29.9 \mathrm{~b}$ & $883 b$ & $998 \mathrm{ab}$ & $1401 \mathrm{a}$ \\
\hline 120 & $8.8 \mathrm{a}$ & 8.7 & $18.7 \mathrm{a}$ & $4.08 \mathrm{a}$ & 5.53 & $3.68 \mathrm{a}$ & $151.3 \mathrm{a}$ & $124.4 \mathrm{a}$ & $157.1 \mathrm{a}$ & $28.8 \mathrm{a}$ & $29.3 \mathrm{a}$ & $37.2 \mathrm{a}$ & $955 \mathrm{a}$ & $1124 \mathrm{a}$ & $1441 \mathrm{a}$ \\
\hline $\mathrm{SE} \pm$ & 0.11 & 0.09 & 0.48 & 0.10 & 0.16 & 0.08 & 2.92 & 6.00 & 3.49 & 2.66 & 2.49 & 1.82 & 22.5 & 55.4 & 79.4 \\
\hline \multicolumn{16}{|c|}{$P$ levels $\left(\mathrm{kg} \mathrm{ha}^{-1}\right)$} \\
\hline 13 & 8.3 & $8.3 \mathrm{a}$ & 17.1 & 3.71 & 5.41 & $3.34 \mathrm{~b}$ & 127.3 & 97.5 & 129.7 & $21.1 \mathrm{~b}$ & $22.3 b$ & 26.7 & $722 \mathrm{c}$ & 847 & 1130 \\
\hline 26 & 8.4 & $8.1 \mathrm{ab}$ & 17.2 & 3.80 & 5.35 & $3.49 \mathrm{ab}$ & 128.8 & 97.5 & 130.0 & $21.3 b$ & $24.14 \mathrm{ab}$ & 27.5 & $873 a$ & 848 & 1130 \\
\hline 39 & 8.5 & $8.1 \mathrm{~b}$ & 18.1 & 3.85 & 5.26 & $3.59 \mathrm{a}$ & 128.9 & 89.1 & 128.2 & $22.7 \mathrm{a}$ & $24.7 \mathrm{a}$ & 30.9 & $809 b$ & 842 & 1127 \\
\hline $\mathrm{SE} \pm$ & 0.09 & 0.08 & 0.42 & 0.09 & 0.15 & 0.07 & 2.52 & 5.18 & 3.02 & 0.51 & 0.68 & 1.47 & 19.5 & 48.0 & 66.8 \\
\hline \multicolumn{16}{|l|}{ Interactions } \\
\hline RXN & NS & NS & NS & NS & NS & NS & $*$ & NS & NS & NS & NS & NS & $*$ & * & NS \\
\hline RXP & NS & NS & NS & NS & NS & NS & NS & NS & NS & NS & NS & NS & NS & NS & NS \\
\hline NXP & NS & NS & NS & NS & NS & NS & NS & * & NS & NS & NS & NS & $*$ & * & NS \\
\hline $\begin{array}{l}\text { RXNX } \\
\text { P }\end{array}$ & NS & NS & NS & NS & NS & NS & NS & NS & NS & NS & NS & NS & $*$ & NS & NS \\
\hline
\end{tabular}

Means followed by the same letter(s) in a column are not significantly different at $\mathrm{P}=0.05$ using DMRT

$\mathrm{NS}=$ Not significantly different at $\mathrm{P}=0.05$

Table 3: Interaction between row arrangement and $N$ levels on maize cob weight in 2007 and grain yield in 2007 and 2008

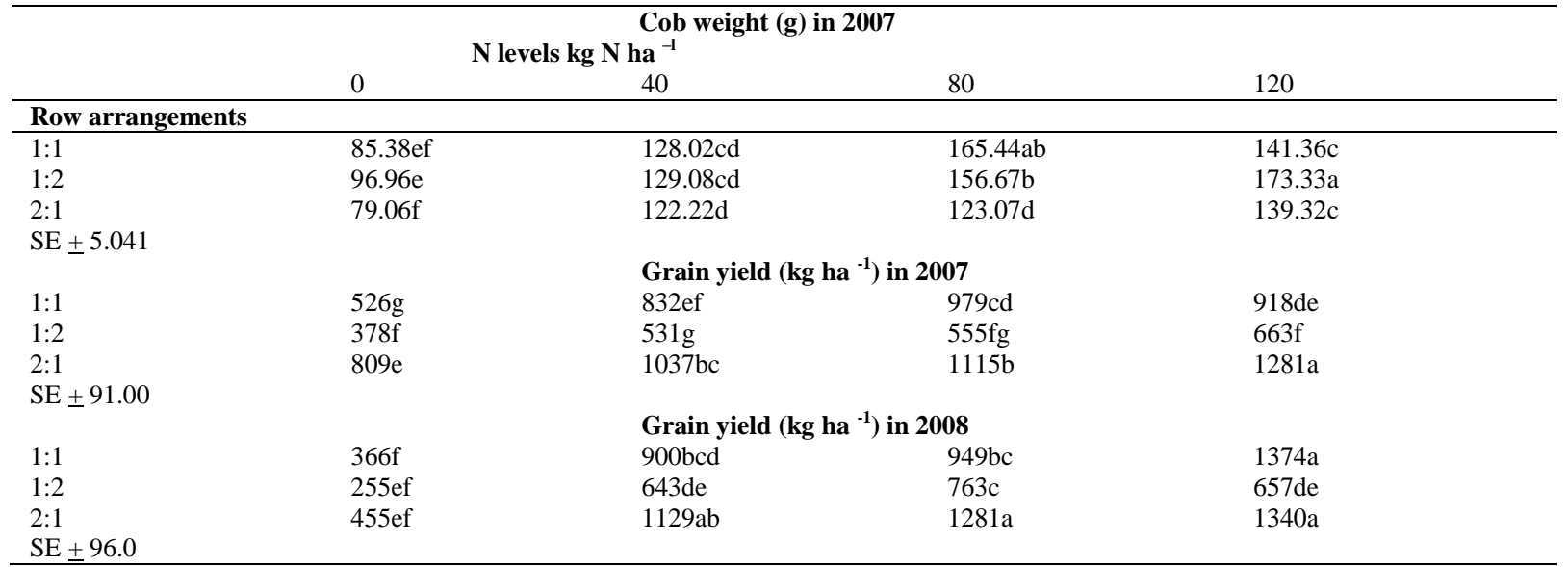

Means having the same letters are not statistically different at $\mathrm{P}=0.05$ (TDMRT) 
Table 4: Interaction between $N$ and $P$ levelS on maize cob weight in 2008 and on grain yield in 2007 and 2008

\begin{tabular}{|c|c|c|c|}
\hline & \multicolumn{2}{|c|}{$\begin{array}{l}\text { Cob weight }(g) \text { in } 2008 \\
P \text { levels kg } P \text { ha }^{-1}\end{array}$} & \multirow[b]{2}{*}{39} \\
\hline & 13 & 26 & \\
\hline \multicolumn{4}{|l|}{$\mathbf{N}$ levels kg $\mathbf{N}$ ha $^{-1}$} \\
\hline 0 & $40.86 \mathrm{~d}$ & $53.51 d$ & $49.29 \mathrm{~d}$ \\
\hline 40 & $83.62 \mathrm{c}$ & $101.27 \mathrm{bc}$ & $105.02 \mathrm{bc}$ \\
\hline 80 & $105.49 \mathrm{bc}$ & $125.16 b$ & $98.79 \mathrm{bc}$ \\
\hline 120 & $159.96 \mathrm{a}$ & $110.02 b c$ & $103.19 b c$ \\
\hline \multicolumn{4}{|l|}{$\mathrm{SE} \pm 3.600$} \\
\hline \multicolumn{4}{|c|}{ Grain yield $\left(\mathrm{kg} \mathrm{ha}^{-1}\right)$ in 2007} \\
\hline 0 & $489 f$ & $631 \mathrm{e}$ & $588 f$ \\
\hline 40 & $787 \mathrm{c}$ & $809 \mathrm{~cd}$ & $804 \mathrm{~cd}$ \\
\hline 80 & $712 \mathrm{de}$ & $1033 a$ & $889 b$ \\
\hline 120 & $901 b c$ & $1024 a$ & $938 \mathrm{ab}$ \\
\hline \multicolumn{4}{|l|}{$\mathrm{SE} \pm 39.9$} \\
\hline \multicolumn{4}{|c|}{ Grain yield $\left(\mathrm{kg} \mathrm{ha}^{-1}\right)$ in 2008} \\
\hline 0 & $280 \mathrm{~d}$ & $388 d$ & $444 d$ \\
\hline 40 & $771 \mathrm{c}$ & $923 b c$ & $978 \mathrm{bc}$ \\
\hline 80 & $972 b c$ & $1078 \mathrm{ab}$ & $926 b c$ \\
\hline 120 & $1363 \mathrm{a}$ & $1026 b c$ & $983 b c$ \\
\hline $\mathrm{SE} \pm 96.0$ & & & \\
\hline
\end{tabular}

Means having the same letters are not statistically different at $\mathrm{P}=0.05$ (TDMRT)

Table 5: Interaction among row arrangement, nitrogen and phosphorus levels on grain yield of maize in 2007

\begin{tabular}{|c|c|c|c|}
\hline \multicolumn{4}{|c|}{ Row arrangement } \\
\hline & $1: 1$ & $1: 2$ & $2: 1$ \\
\hline \multicolumn{4}{|c|}{$\mathbf{N}+\mathbf{P}$ Levels $\left(\mathrm{kg} \mathrm{N}+\mathbf{P}\right.$ ha $\left.^{-1}\right)$} \\
\hline $0+13$ & 489np & $287 q$ & 690ijkl \\
\hline $0+26$ & $532 \mathrm{mnp}$ & 428np & $967 f$ \\
\hline $0+39$ & $572 \mathrm{~m}$ & $416 \mathrm{p}$ & 771hij \\
\hline $40+13$ & $788 \mathrm{ghi}$ & 454np & $118 \mathrm{~d}$ \\
\hline $40+26$ & $831 \mathrm{gh}$ & $5961 \mathrm{~m}$ & 1001ef \\
\hline $40+39$ & $877 \mathrm{fg}$ & $541 \mathrm{mn}$ & $993 \mathrm{ef}$ \\
\hline $80+13$ & $811 \mathrm{gh}$ & $478 n p$ & $846 \mathrm{gh}$ \\
\hline $80+26$ & $1097 \mathrm{de}$ & $671 \mathrm{jkl}$ & $1309 \mathrm{~b}$ \\
\hline $80+39$ & $994 \mathrm{e}$ & $518 n$ & $119 \mathrm{~cd}$ \\
\hline $120+13$ & $902 \mathrm{fg}$ & $642 \mathrm{klm}$ & $1159 \mathrm{c}$ \\
\hline $120+26$ & 1088de & 740hij & $1441 \mathrm{a}$ \\
\hline $120+39$ & 765hij & 6081 & $1249 b c$ \\
\hline $\mathrm{SE} \pm 38.9$ & & & \\
\hline
\end{tabular}

Means having the same letters are not statistically different at $\mathrm{P}=0.05$ (TDMRT) 